\title{
RELATIVE EVALUATION OF AGRICULTURAL LAND \\ FOR PURPOSES OF LAND CONSOLIDATION
}

\section{Aina Palabinska, Anda Jankava}

Latvia University of Agriculture

aina.palabinska@1lu.lv, anda.jankava@1lu.lv

\begin{abstract}
The main tasks of land consolidation are to eliminate land fragmentation and to facilitate farms of optimal size. One of the most important preconditions of land consolidation is forming of optimal size farmland plots in property and use, and land fragmentation, which has a major impact on both the operating conditions and other rural development processes. Land fragmentation bothers not only land management, but also increases transport costs. During the land reform in the rural areas, land plots in ownership and rented land plots are developed per several land units. The other factor contributing to the fragmentation of farmlands is the development of the land market, because it is not always possible to find land next to the owner's farmland for purchasing or leasing the land for the purpose of the land area increasing. In The Land Management Law, which was adopted in 2014 by the Saeima of the Republic of Latvia, which aim was to establish a legal basis for rational land use and sustainable spatial development, the agricultural land consolidation was emphasized. In the process of land consolidation an equivalent land exchange between agricultural landowners is carried out. Foreign experience shows that different values are applied, for example, in Germany the so-called relative value of agricultural land is calculated on the bases of land's qualitative assessments. Also in Latvia some activities have been carried out in the land relative assessment for the land consolidation needs. A pilot project on agricultural land relative assessment in 2016 was carried out for land consolidation needs under the guidance of the article's authors in cooperation with the State Land Service. The aim of the paper is to examine the method of land assessment and analyse its suitability for the land parcel exchange for the purpose of the land consolidation pilot project.
\end{abstract}

Keywords: land consolidation, relative evaluation, qualitative assessment of land.

\section{Introduction}

Sustainable economic development, including sustainable use and protection of land and nature resources, has been mentioned in the majority of strategic planning documents adopted in the Republic of Latvia in compliance with the directives of the European Union. For example, the aim of the Strategic Objective of "Sustainable Management of Natural and Cultural Capital" in the priority "Growth for Regions" of the National Development Plan of Latvia for 2014-2020 is "to maintain of the natural capital as the basis for sustainable economic growth and promote its sustainable use while minimizing natural and human risks to the quality of the environment" [1]. Tasks related to this objective are to promote the sustainable use and biological diversity of land and other natural resources simultaneously preventing them from unfavourable conditions. The "Sustainable Development Strategy of Latvia until 2030" mentions that tendencies in the recent years show that the number of persons employed in agriculture and their desire to work in agricultural production have reduced in the countryside. Therefore, large areas of agricultural land are not used for agricultural production and are gradually overgrowing thus degrading the environment of rural territories. This is due to the large number of small farms where it is not possible to carry competitive traditional agricultural production [2]. The authors found that the size of more than a half of farms does not reach 10 ha, and the size of more than $10 \%$ of farms does not exceed 2.4 ha even though the situation has been improving recently [3].

The great number of small farms is the result of the land reform, which did not state the minimum size of the allocated land and, simultaneously with the land privatisation process, the land market and large scale agricultural production developed creating large farms, which occupied even more than 1,000 ha of agricultural land. The deals with land resulted in expansion of the size of land for large farms, but not always farmers could buy or rent the neighbouring land. Thus land properties became rather fragmented consisting of many remote parcels of land situated up to several tens of kilometres from each other. The fragmented agricultural land hampers the use of agricultural machinery and increases the production costs. This condition caused another problem: abandoned and unused land territories appeared becoming a widely discussed issue both in the European Union and Latvia [4]. 
Consequently, the issue of land consolidation is now back on the agenda, which has been used already from the 18th century in the Western Europe as the measure of promoting sustainable rural development.

The "Sustainable Development Strategy of Latvia until 2030" clarifies that "it is necessary to support the consolidation of valuable agricultural lands and the formation of larger producing farms, improving the competitiveness of the sector in export markets concurrently taking into account and assessing the ecological, aesthetical and cultural and historical value of landscapes" [7]. The term land consolidation is traditionally used to describe measures of prevention of land fragmentation and an increase of farmland expansion. However, it is used not only concerning land reallocation and prevention of fragmentation, but also in a broader sense. The land consolidation may promote nature and landscape protection as well as serve as support instruments for increasing of farmland expansion. The term land consolidation came into use in the 90-ties of the previous century. Speaking about the legislation of Latvia, the term land consolidation for the first time appeared in the Land Survey Law adopted on September 14, 2006, as one of the land management planning project tasks, however, later in the Amendments to the Land Survey Law, adopted on November 12, 2015, land consolidation was deleted. As an explanation it should be noted that no land consolidation projects have been worked out since the adoption of the law. Moreover, except for two small-scale pilot projects implemented with the assistance of Danish specialists before the adoption of the law, there are no examples of land consolidation activities in Latvia. The study of the experience of land consolidation in other countries gives information that many rural land consolidation projects have been worked out in Lithuania, which along with the experience of Western European countries, have been analysed and reflected in scientific publications of Lithuanian and European countries [5-9]. As regards Estonia, very fragmented structure of agricultural lands has been formed as a result of the last land reform; the Land Readjustment Act adopted in 1995 is outdated and ineffective due to its very complicated procedure. Some experience of land consolidation has been acquired during implementation of the land reform, however, the improvement of the law is necessary. The recent publications show that the work is in the process since Estonian farmers are interested in participation in the land consolidation process [10].

Land consolidation involves the exchange of land parcels of equal value. Therefore, one of the most complicated stages of the process is to find land parcels of the same value. The question is: what kind of value should be used? Usually land market value is used in transactions with land, but some Western European researchers and specialists, for example, Professor Thomas [11] and FAO [5], point out that value may be based on market value in combination with the soil quality, but Van Dijk [12] considers that market value should not be used when consolidating land. Thus, another value is necessary. For example, in Germany land assessment for the purposes of land consolidation occurs depending on the types of land-use - agriculture land, forest land and construction land. In order to provide land of the same value for exchange in the land consolidation process, agricultural land is evaluated on the basis of soil samples and other factors, i.e., relief, closeness of forest, accessibility; the land in the consolidation process is divided into classes $[13 ; 14]$.

The Land Management Law is in force in Latvia since January 1, 2015. The entire section of the law is devoted to land consolidation describing the procedure of complex land boundary redesign to form a rational structure of farms and parcels, promote rural infrastructure and rural development as well as environmental protection within the framework of land consolidation [15]. The State Land Service (hereinafter referred to as SLS) is responsible for the implementation of the land consolidation project. SLS staff has worked out the method of relative land assessment in the land consolidation process. The aim of the paper is to examine the method of land assessment and analyse its suitability for the land parcel exchange for the purpose of the land consolidation pilot project.

\section{Materials and methods}

The aim of the Land Management Law is to form the legal basis for rational land use and sustainable development of the territory, as well as to adjust private ownership interests and public land needs for the future use [1]. It is necessary to provide public services for public needs. It requires land use plans with appropriate land parcels for public roads and other transport infrastructure objects. 
Consequently, rearrangement of boundaries of existing land units and exchange of the same value land units are necessary to perform, which is therefore the main task of land consolidation.

Separated areas allocated for the land consolidation project cover land properties, which consist of land units with different environmental and technological conditions, for example, different types of soil, soil reaction $(\mathrm{pH})$, humidity conditions, etc.

All the above conditions influence the degree of land cultivation and its quality assessment [16]. To observe the equality principle, the quality and size of the land should be taken into account, therefore, the size of land property to be consolidated can increase, decrease or remain the same in comparison with the current situation during the exchange process of land units (Fig. 1).

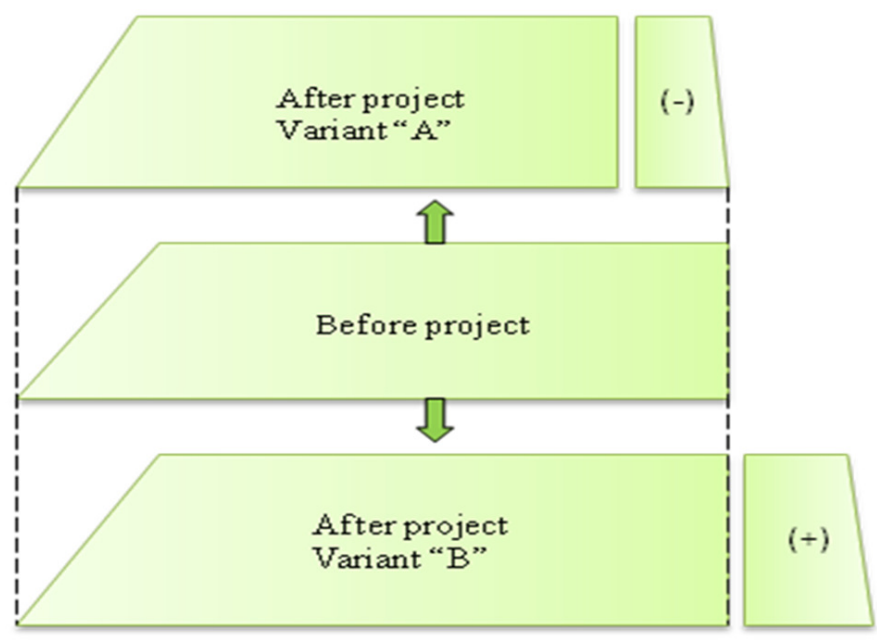

Fig. 1. Variants of the possible change of the total area of the property after the project

In 2015 the State Land Service worked out the method for implementation of land consolidation "Land Relative Assessment for Land Consolidation", which determined that any land consolidation project should be worked out on the basis of relative assessment ratio of separate land units [17].

According to this method, land relative assessment is a value expressed in points, which does not change the value of land units in land market before and after the land consolidation project [17]. The points of land relative assessment are necessary in order to secure the process of redesigning boundaries because more detailed information is necessary on each land unit due to heterogeneous nature of Latvia's rural land. For example, one land unit may contain agricultural land with different types of soil, granular content of soil and different qualitative assessment (Fig. 2a).

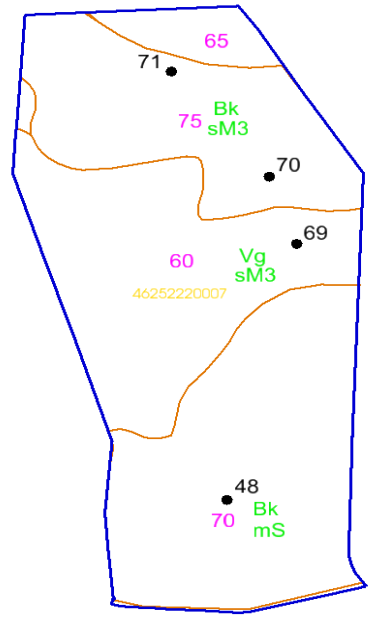

a)

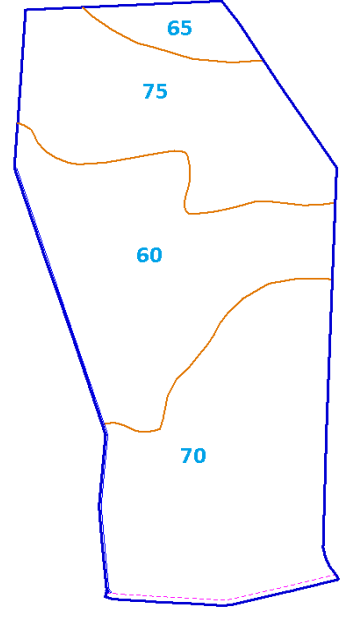

b)
Labels:

75 - qualitative assessment, points;

$\mathrm{Vg}$ - type of soil;

$\mathrm{mS}-$ group of granular content;

- 69 - number of a hole; 60 - relative assessment, points per 1 ha

Fig. 2. Contours in land units with different indicators: a - extract of a map with soil and land qualitative assessment; $b$ - extract of a map with relative assessment 
It was necessary to work out a relative assessment map for the area included in the land consolidation project with contours of land-use and soil distribution indicating relative assessment points for comparison per one area unit (per $1 \mathrm{ha}$ ) (Fig. 2b), which also can serve as a designing instrument for the consolidation project.

To assess the redesign result both for a separate land unit and for the property on the whole, it is necessary to calculate the total number of points of relative assessment. The point system is supposed to be used for a soil map and land quality assessment map (Fig. 2a). Land qualitative assessment includes combination of the factors determining the quality of land: type of soil, its granular content, humidity conditions, land cultivation degree etc. Therefore, the qualitative assessment of agricultural land is one of the main influencing factors of land market value. To determine relative assessment of agricultural land, it is suggested to use land's qualitative assessment in points, where one point equals one relative assessment point.

Concerning relative assessment of forest land, forest land qualitative assessment in points is used according to the forest inventory records and the type of forest growth conditions.

Besides, land units may comprise areas with non-agricultural land-use (shrubs, land under water bodies, buildings and courtyards, land under roads and swamps), which is defined as other land. Consequently, relative assessment for other land indicated as a contour is entitled to be determined in comparison with agricultural land; it means that the $1^{\text {st }}$ quality group's basic value of existing agricultural land is used for relative assessment of these contours, which are adjusted by a factor 0.8 according to the following formula [16]:

$$
R=B_{v} \cdot P \cdot 0.8,
$$

where $R$-relative assessment;

$B_{V}$ - basic value of agricultural land's $1^{\text {st }}$ quality group;

$P$ - area of a contour;

0.8 - adjustment factor.

The total relative amount of a land unit is expressed as a sum of points (a sum of multiplied area of a land contour and respective points per $1 \mathrm{ha}$ ). But the total relative assessment of the entire property is the total sum of relative assessment for all land units of the property involved in the consolidation process, expressed in points. The method for implementation of land consolidation "Land Relative Assessment for Land Consolidation" [17] was put into practice in 2016 by members of the academic staff of the Latvia University of Agriculture (the authors of the article) in cooperation with the SLS staff members and students in the venue of Auce parish, Auce municipality, Latvia.

Redesign of land units' boundaries in the framework of the pilot project was conducted for the needs of a road/rail transport infrastructure object. Five land properties (labelled Property A,B,C,D,E, accordingly) were selected for the pilot project with the total area of 142.62 ha, which could supposedly be crossed by a prospective transport infrastructure line. The land-use aim of the registered real estate land units of the pilot project was "agricultural land". The new transport line across the area of the project would divide some land units forming areas unsuitable for agricultural production, interareas, inconvenient boundaries, inaccessible territories (Fig. 3). The aim of the project was to redistribute land creating compact rural properties by decreasing the size of inter-areas and providing better access to the properties.

The project was divided into three stages:

- preparatory stage;

- field survey;

- data processing, creating maps, cartographic design, land consolidation project design.

The first stage involved the analysis of the previous data obtained during the last soil mapping and land assessment (1988) of the area included in the pilot project [18]. The boundaries of land units were matched with the plan of Auce municipality plans, drainage system planning, an orthophoto map, a digital soil map and relief map. The data ware summarized and cartographic materials were prepared during the preparatory stage. 
The second stage, the field work, involved the examination of the entire territory included in the pilot project. The total area, its distribution among the types of use and their sizes were checked in the field with the assistance of the measurement tool "GPS Juno".

Due to the fact that the previous soil mapping and land assessment were performed almost 30 years ago, it was necessary to conduct the qualitative assessment of land. Therefore, the soil was tested and soil samples were obtained to determine the type of soil, the group of granular content, carbonation depth, humus thickness and soil reaction $(\mathrm{pH})$.

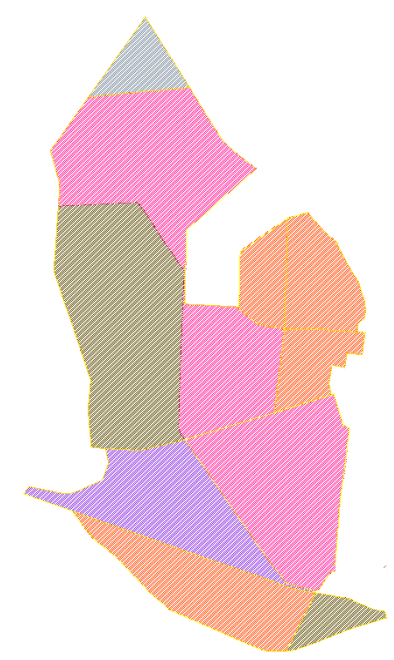

a) before land consolidation

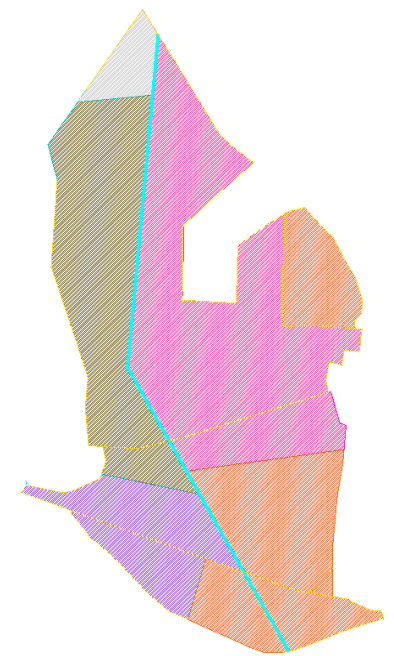

b) after land consolidation
Label of property:

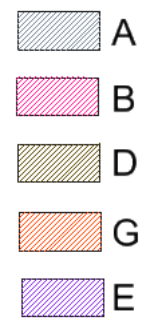

Fig. 3. Location of property before and after land consolidation project

Special tools for conducting the measurements and obtaining data were used: a soil probe, a universal indicator, $10 \%$ hydrochloric acid and $\mathrm{pH}$-measuring instrument. The obtained samples were evaluated according to 16 criteria and immediately compared with the previous data from 1988 recording changes, which occurred during the last 28 years. Simultaneously, encumbrances and their types were determined during the inspection of the land units to be used for evaluation of the degree of land cultivation and land quality assessment.

Cartographic materials and tables were designed on the basis of the data obtained during the field survey and the analysis of the available information of the object of the land consolidation project: boundary maps of land units, encumbrance plans, soil maps. In addition, the information on land-use types in the pilot project's land units was updated. Thus, the isoline soil map was designed on the basis of the field survey data, where contour lines in each land unit illustrated a type of soil, a group of granular content of soil and land quality assessment in points, for example, a contour line with sod podzolic soil, light loam and quality assessment of 45 points received the symbols $\mathrm{Pv} \mathrm{sM}_{3} 45$ (Fig. 2a).

The third stage involved:

- analysis of the obtained data;

- design of cartographic materials;

- development of the land consolidation project (the land exchange due to redistribution of land units for the building needs of a new transport infrastructure object).

MicroStation Bentley software was used for designing cartographic materials. The cultivation level of agricultural land and its quality was assessed using the method indicated in the regulations of cadastral assessment [16].

\section{Results and discussion}

Several changes were detected during the field survey of land units of the land consolidation project in comparison with the situation, which was determined during soil mapping and the land assessment procedure in 1988 [18]. In some cases the type of land-use has been changed: arable land has appeared instead of pasture; besides, several quality decreasing factors were found, such as 
stoniness, worsened moisture conditions, emerging soil erosion, rather many electricity poles, unused livestock watering facilities in the former pastures in the current fields of arable land; it was found that soil composition and granular content in areas of arable land near drainage ditches have changed as a result of deepening of such ditches.

All of the above mentioned conditions were taken into account when assessing the degree of land cultivation and land quality in their distribution across contours. For example, the quality assessment was reduced by 5 to 8 points in certain land units in comparison with the previous assessment in 1988, but one specific land unit received the assessment, which was by 17 points less than in 1988 .

The soil and land quality map (Fig. 2a) designed on the basis of the field survey was used for the relative assessment of land, where all land units of the consolidation project were divided into separate contours with different indicators for the type of soil, granular content and quality assessment. The land relative assessment in points was calculated per 1 ha for each separate contour (Fig. 2b) and for the entire contour in total using the method worked out by the State Land Service [17]. In this way, the total land relative assessment of each property involved in the pilot project before the land consolidation project implementation was obtained by summing up the points of relative assessment of separate contours of land units (Tab. 1).

Table 1

Total relative assessment of property before and after the project in points

\begin{tabular}{|c|c|c|c|c|c|c|}
\hline \multirow{2}{*}{ 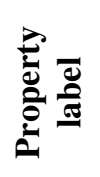 } & \multicolumn{3}{|c|}{ Total area of property, ha } & \multicolumn{3}{|c|}{ Total relative assessment of property, points } \\
\hline & before project & after project & difference & before project & after project & difference \\
\hline A & 4.56 & 4.56 & 0 & 296 & 296 & 0 \\
\hline B & 60.82 & 56.69 & -4.13 & 3405 & 3407 & 2 \\
\hline $\mathrm{D}$ & 34.04 & 35.00 & 0.96 & 2217 & 2221 & 4 \\
\hline $\mathrm{G}$ & 17.45 & 16.47 & $\begin{array}{l}-0.98 \\
\end{array}$ & 695 & 697 & 2 \\
\hline$E$ & 25.75 & 29.81 & 4.06 & 1367 & 1360 & -7 \\
\hline Total: & 142.62 & 142.53 & -0.09 & 7980 & 7981 & 1 \\
\hline
\end{tabular}

Thus, two digital maps of land relative assessment in points per 1 ha (Fig.2b) and in points per contour had been designed on the basis of the obtained data before the project, which later were used for redesigning boundaries of land units. The total land relative assessment was calculated in points on the basis of images of each property involved (A, B, D, G and E) before the beginning of the pilot project (Tab. 1).

Design of a prospective new line of transport infrastructure caused division of many land units of the properties involved in the project. If a highway of a national significance was intended in this territory, turnoffs would not be possible to plan everywhere, thus some of the separated land units could not have an access to the highway. A similar situation would also be the case if a new railway line was intended to design. Consequently, the aim of the land consolidation project would be to design land properties of appropriate shape with accessibility to roads and highways.

Redesign of land unit boundaries was conducted in the framework of the pilot project (Fig. 3b) taking into account the current situation (location of roads, ditches), as well as the total amount of points of relative assessment for each land unit (Tab. 1).

Since quality assessment was very different for land units involved in the pilot project (from 25 to 75), after redesign of the land unit boundaries it was found that only one land property involved in the pilot project had the same total relative assessment before and after the project (Property A). The total relative assessment before and after the project of other properties differed and the largest difference was found for Property E, since the relative assessment of land of Property E has decreased by 7 points in comparison with the current situation (Tab. 1).

Table 1 shows that a similar situation after the project was observed in the distribution according to the total area of property: the total area of only one property (Property A) did not change, but the 
most noticeable changes in the total area of property before and after the project happened to Properties B and E, i.e., it was 4.13 ha un 4.06 ha, respectively.

\section{Conclusions}

1. Land consolidation is a topical issue in Latvia. Land consolidation has been used in the Western Europe since the 18th century as a sustainable rural development measure. Land consolidation measures are used to prevent fragmentation, increase the size of land in rural areas and develop infrastructure improvement projects, especially road infrastructure objects.

2. The soil mapping and land quality assessment data obtained in the 80-ties of the previous century in Latvia do not correspond to the current situation due to significant changes both in soil and properties.

3. The method of relative land assessment worked out by the State Land Service, expressed in points, is suitable for the development of land consolidation projects, since it comprehensively evaluates both land quality and territorial features, providing equivalence in case of land exchange deals.

4. Land consolidation involving redesigning boundaries of land units not always observes the principle of equality among land properties before and after land consolidation projects due to different soil and land indicators influencing the relative assessment of land.

\section{References}

1. Latvijas Nacionālais attīstības plāns 2014.-2020.gadam, Pārresoru koordinācijas centrs (National Development Plan of Latvia, years 2014-2020). (In Latvian) [online] [03.03.2017]. Available at: http://www.varam.gov.lv/lat/pol/ppd/ilgtsp_att/?d oc $=13858$

2. Latvijas ilgtspējīgas attīstības stratêgija līdz 2030.gadam (Latvia 2030 Sustainable Development Strategy). (In Latvian) [online] [03.03.2017]. Available at: http://www.pkc.gov.lv/images/LV2030/Latvija_2030.pdf

3. Platonova D., Jankava A. Description of Land Fragmentation in Latvia and its Prevention Opportunities. Rural Sustainability Reseach: Proceedings of the Latvia University of Agriculture. Vol. 28. Issue 1, 2012, pp. 1-8. [online] [15.03.2017]. Available at:

https://www.degruyter.com/view/j/plua.2012.28.issue-1/v10236-012-0009-y/v10236-012-0009y.xml.

4. Platonova D., Jankava A. Zemes konsolidācija kā instruments veiksmīgai saimniekošanai (Land Consolidation as a tool for its successful management). Zinātniski praktiskās konferences "Lauksaimniecības zinātne veiksmīgai saimniekošanai" raksti, Jelgava, Latvija, 21.-22. februāris, 2013 / LLU LF, Latvijas Agronomu Biedrība, Latvijas Lauksaimniecības un meža zinātṇu akadēmija, Valsts Lauku tīkls. Jelgava: LLU, 2013, 91-97 pp.

5. FAO The Design of Land Consolidation Pilot Projects in Central and Eastern Europe: FAO Land Tenure Studies, No 6 / Food and Agricultural organization of the United Nations. - Rome. 2003, $58 \mathrm{p}$.

6. Hartvigsen M. Land Consolidation in Central and Eastern European Countries, XXIII FIG Congress, Munich, Germany, October 8-13, 2006.

7. Pasakarnis G., Maliene V. Land Readjustment for Sustainable Rural Development. "KnowledgeBased Technologies and OR Methodologies for Strategic Decisions of Sustainable Development": 5th International Vilnius Conference, EURO Mini Conference (KORSD-2009), sept. 30-okt. 3, 2009/ Vilnius: Institute of Mathematics and Informatics, Vilnius Gediminas Technical University, 2009, pp. 169-174.

8. Pasakarnis G., Morley D., Maliene V. Rural development and challenges establiching sustainable land use in Eastern European countries. In.: Land Use Policy, Vol. 30, Jan. 2013, pp. 703-710.

9. Platonova D., Jankava A. The necessity of land consolidation assessment in Latvia. The 6th International scientific conference "Rural Development 2013: Innovations and sustainability": proceedings, 28-29 November, 2013, Akademija, Kaunas district, Lithuania / Aleksandras Stulginskis University. Kaunas : Akademija, 2013. Vol.6, Book 1, pp. 283-288.

10. Jürgenson E. Land reform, land fragmentation and perspectives for future land consolidation in Estonia. In.: Land Use Policy, Vol. 57, May, 2016, pp. 34-43. 
11. Thomas J. What's on Regarding Land Consolidation in Europe? In: Proceedings of the XXIII FIG Congress, Shaping the Change, October 8-13, Munich, Germany 2006..[online][10.03.2017]. Available from URL: http://www.fig.net/pub/fig2006/papers/ts80/ts80_03_thomas_0311.pdf

12. Van Dijk T. Dealing with Central European Land Fragmentation. A critical assessment on the use of Western European instruments. Eburon, Delft, 2003, p. 15-24.

13. Die Wertermittlung in der Flurbereinigung - Leitfaden fuer Vorstandsmitglieder. Bayerische Staatsministerium fuer Ernaerung (1988). Landwirtschaft und Forsten. Muenchen. 64 p.

14. Thomas J. Verfahrensablauf der Flurbereinigung. In: Kummer K., Frankenberger J. (Hrsg.) Das deutsche Vermessungs- und Geoinformatiomnswesen 2013. Germany, Berlin und Offenbach: H.Heenemann GmgH \& Co, KG, 2013, pp. 437-521.

15. Zemes pārvaldības likums (Land Management Law), 2014, (In Latvian) [online] [10.03.2017]. Available: https://likumi.lv/doc.php?id=270317.

16. Kadastrālās vērtēšanas noteikumi (2006) Regulations No. 305 of the Cabinet of Ministers. Regulations regarding Cadastral Assessment. In force since April 18, 2006.

17. Par Zemes relatīvā novērtējuma noteikšanu zemes konsolidācijas vajadzībām. VZD metodika. 2015. 24 lp.

18. Dobeles rajona Auces ciema mācību izmēǵinājumu saimniecības "Vecauce" Augsnes kartēšanas un zemes vērtēšanas lieta(1991). Instit. "Zemesprojekts". 